\title{
Transversal Skills in Mathematics Curriculums of Latvian Secondary Education: 1940-2020
}

\author{
Gatis Lāma ${ }^{1}$ Mg. math.; Rudīte Andersone ${ }^{2}$ Dr. paed. \\ University of Latvia, Latvia \\ gatis.lama@lu.lv¹; rudite.andersone@lu.lv²
}

\begin{abstract}
Digital technologies are rapidly changing our daily lives and work environment, encouraging the review of current curriculums in schools. The implementation of the new curriculum in Latvian schools begins on September $1^{\text {st }}, 2020$. As transversal skills as a term are included for the first time, teachers feel confused regarding the inclusion of such skills in the learning process and the implementation of experience in practice in the new context, simultaneously raising doubts about their professional capacity in practice, teachers are guided by the requirements of the curriculum. The study focuses on the analysis of 11 secondary school mathematics curriculums, using document analysis. The aim of the research is to analyse transversal skills and their development in secondary school mathematics curriculums, by analysing various mathematics curriculums in Latvia from 1940 to 2020. It is essential to accentuate the importance of transversal skills and content that has assisted in the development of transversal skills in earlier teaching practice, to aid teachers in choosing methods and activities that are applicable, as well as necessary changes to achieve new education goals. The research results indicate that transversal skills have been essential in previous mathematics curriculums. The most important transversal skills that have been highlighted in all analysed curriculums are thinking skills, skills that are necessary for individual work and career skills. The new challenges are related to transversal skills that are required for civic activity, the use of different learning methods and lifelong learning.
\end{abstract}

Keywords: secondary education, mathematics curriculum, transversal skills.

\section{Introduction}

There are significant changes in society which have an impact on learning and work environment, and therefore, the necessity for transversal skills has increased significantly (European Commission, 2018; European Commission, 2019) as an instrument for lifelong learning, as well as a skill set required for everyone to navigate in today's changing world. Students should be prepared for jobs not yet created, technologies that have not been invented or even are not imaginable yet (OECD, 2019). The development of transversal skills is not only important for students to prepare for future job or education challenges, but it is essential for students to be properly prepared for a meaningful, sustainable and responsible life in a rapidly changing and interconnected world (Trzmiel, 2015). Although transversal skills and their role have been studied for several decades in the context of education, there are still significant challenges related to both the use of terminology and the meaningful implementation in every-day practice and school curriculum.

There are many terms to refer to general skills applied in the various initiatives which define and improve the understanding of the concept of transversal skills. All terms used to refer to transversal skills, for instance, non-technical skills, 21st century skills, transferable skills, soft skills, generic skills and many other terms, generally relate to the skills, competencies, values and attitudes essential for the comprehensive development of learners, such as cooperation, self-discipline, resourcefulness and respect for the environment (Trzmiel, 2015). The origin and use of various terms may relate to local, governmental, or global characteristics and needs. The wide variety of terms leads to inconsistency that significantly complicates the research process. There is still no clear view on how best to prepare pupils for a successful and meaningful life outside the classroom (Trzmiel, 2015) and which of the skills are needed to overcome these challenges.

Since the integration of transversal skills into education practices may require significant changes in the learning methodology, the implementation of this process is closely linked to teachers and their professional activities (Trzmiel, 2015). One of the most significant challenges of the teacher's day-to-day classroom activities is the lack of understanding of the necessity to change their learning and evaluation practice (Care, Luo, 2016). Transversal skills are widely applied; interdisciplinary skills that go beyond a specific area or curriculum (Flora, 2014) are needed to successfully adapt to changes and live a meaningful and productive 
life (Trzmiel, 2015). Transversal skills are characterised by personal autonomy and responsibility, social interaction, personal and professional development (Ipate, Mitran, Pârvu, 2014).

The new curriculum implementation process has been started in Latvian schools since September $1^{\text {st }}$, 2020 (Skola 2030, 2018). This is the first school curriculum in Latvia, which refers to the actual term "transversal skills". To change current classroom practice and to successfully introduce the new content, it is essential to comprehend that although part of transversal skills has not been included in previous school curriculums, a large part of transversal skills, directly or indirectly, can be found in previous school curriculums and has been developed in the learning process for many years.

Consequently, there is a need to analyse previous and new curriculums, raise awareness and distinguish which transversal skills are actually well-known and have already been successfully included in classroom practice for decades, and which of the skills in the curriculum are newly introduced, thus, requiring teachers to devote additional attention to adjust the teaching methodology to address this challenge. Such an approach would allow teachers not only to better understand the nature of transversal skills by connecting new methods and knowledge with previous practices, and would allow them to focus on the development of transversal skills that have been integrated into the curriculum relatively recently. Better understanding of transversal skills and their connection with secondary school mathematics would not only lead to a better understanding of transversal skills and their importance in teaching practice, but would address one of the major challenges of integrating transversal skills - teachers' heavy workload (Trzmiel, 2015).

Transversal skills can be integrated into the school curriculum in three ways (Gordon et al., 2009):

\section{- Developing transversal skills in a specific subject}

The acquisition of transversal skills is included in the curriculum as a specific subject with specific objectives and formal learning goals.

- Developing transversal skills by integrating them into each subject (cross-subject)

Development of transversal skills occurs in all traditional subjects.

- Developing transversal skills with extra curriculum activities

Accordingly, the aim of the research is to analyse the variability of transversal skills in secondary school mathematics curriculums, by analysing the importance of transversal skills in various Latvian secondary school mathematic curriculums from 1940 to 2020.

\section{Methodology}

The researchers, using document analysis, selected various secondary school mathematics curriculums from 1940 to 2020. Overall, 11 different secondary school mathematics curriculums are analysed: Mathematics curriculum (Tartakovskis et al., 1940), Mathematics curriculum. Grades V-XI (Matemātikas programma..., 1949), Mathematics curriculum. Grades V-XI (Matemātikas programma..., 1953), Mathematics curriculum. Grades V-XI (Matemātikas programma..., 1958), Mathematics curriculum for secondary schools. Grades IX-XI (Matemātikas programma..., 1965), Mathematics curriculum for secondary schools. Grades IX-XI (Matemātikas programmas..., 1968), Mathematics curriculum for secondary schools. Grades IX-XI (Matemātikas programma..., 1975), Mathematics curriculum. Grades IX-XI (Matemātikas programma..., 1981), Secondary education curriculum in mathematics (Vidējās izglītības standarts..., 1993), Mathematics. Grades 10-12. Sample of curriculum (Matemātika 10.-12. klasei..., 2010), Mathematics I. Basic course curriculum for general secondary education (Vilciņš et al., 2020). Over the years, the duration of high school has changed as well as the age of students starting secondary school. In 1940 students had to study in secondary school for 6 years and the students started secondary education at the age of 11 , it has reduced over time to 3 years: nowadays students start secondary school at approximately age 16 . As part of this research, the last three secondary education years are considered secondary school. In the analysis of the common characteristics of secondary education curriculums, transversal skills were grouped into unitary domains (Table 1):

- transversal skills required to address secondary school mathematical challenges,

- transversal skills required for the use of different teaching methods,

- transversal skills needed for everyday life and that can be developed through secondary school mathematics. 


\section{Results and Discussion}

The analysis of the transversal skills required to address secondary school mathematical challenges, shows that these skills are sustainable and very similar in all analysed secondary school curriculums. The reason for transversal skill sustainability is also determined by the similarity and resilience of the mathematical content in secondary school mathematics. The content of secondary school mathematics determines the need for different thinking skills, problem solving skills and research skills, and in the context of geometry spatial imaginations. Thinking skills, as a key element required in each mathematics topic, include analysis, generalization, and demonstration skills, the use of deduction and induction, analogy, mathematical proof, interpreting and many others. Without these skills, it is impossible to acquire mathematical knowledge and develop technical or subject skills (Vorobjovs, 2019). Even more, in the context of secondary school mathematics these skills should be considered technical or subject skills. Over the years, there is a trend for secondary school mathematic curriculums to be increasingly detailed which means that the intensity of mentioning transversal skills is increasing as well, and skills can be specified in a more detailed manner as well.

From 1949 to 1981, thinking skills are included as a short and concise learning objective: to develop logical thinking. More detailed information about these skills can be gained only by analysing mathematics content which leaves a place for interpretation. Since 1993, a more general objective has emerged in the secondary education mathematics curriculum - the development of thinking techniques. It is described more detailed in new secondary education mathematics curriculum in 2020 by highlighting skills like analysing, interpreting, reasoning, proving, generalizing and many other thinking components.

Similarly like with thinking skills, problem solving skills as a term indirectly appears in secondary school mathematics curriculum since 2010, defined as a problem formulation and raising hypothesis (Matemātika 10.-12. klasei..., 2010), and in 2020 - as problem solving (Vilcinš et al., 2020). However, these skills have always been important in secondary school mathematics and have been included in curriculums in an indirect way, as shown by the mathematics content. For example, problem solving skills had to be developed through solving different types of textual tasks which requires problem solving skills and has been included in secondary school mathematics curriculum since 1940 (Tartakovskis et al., 1940).

The analysis of the transversal skills required for the use of different learning methods shows the significant variability of methods used in secondary school mathematics over years, caused by paradigm change. Following the adoption of the Latvian Declaration of Independence on 4 May 1990, the process of democratisation starts in Latvian schools, which increased the freedom of the teacher in the implementation of the learning process, delegating the right and responsibility to organise the training process independently to the teacher. It was allowed to include some new topics as well as change the depth of the content provided in the curriculum (Vidējās izglìtîbas standarts..., 1993). These processes also start a transition from teacher-centred to student-centred approach.

Individual work methods dominate over other learning methods up until 1993. Individual activity of the student is essential to the day-to-day learning process, and provides skills for independent (Matemātikas programma..., 1965; Matemātikas programmas..., 1968; Matemātikas programma..., 1975) and rational work (Matemātikas programma..., 1949; Matemātikas programma..., 1953; Matemātikas programma..., 1958; Matemātikas programma..., 1981), as well as persistence in achieving the stated objective. Although the methods used until 1993 were limited to individual work, there is a comprehensive application of teaching methods, including the need for students to be able to work with books, manuals and other literature, tables, and charts individually. In addition, the secondary school curriculum outlines the need for extra curriculum activities, for example, after school mathematics, school papers, evenings with mathematical games. This kind of extra curriculum activities increase students' interest in mathematics. Although there is no detailed explanation and methods to be used for extra curriculum activities and the skills needed for students to participate in these activities are not specified, the nature of these activities indicates the need to collaborate (Vorobjovs, 2017, Lama, 2020), which means that transversal skills required to successfully work in teams were partly developed in extra curriculum activities.

Since the restoration of independence, secondary education curriculum has been supplemented with many different learning and teaching methods. For example, the 2010 secondary education mathematics curriculum includes a section with different teaching methods. Such methods as inquiry, laboratory 
work, research project, games, role play, problem solving as a teaching method and many others are included in the curriculum.

In all analysed secondary school mathematic curriculums, the necessity to use topical innovations in the learning process has been stressed. From 1968 to 1975 pupils were urged to use a logarithmic ruler, later in 1993 - a micro calculator, and finally, since 2010, the application of a variety of digital technologies has been encouraged.

Regarding transversal skills which is needed for everyday life and may be developed through secondary school mathematics, only career skills (defined as 'skills for practical work') are included in this category up until 1993. From 2010, secondary education mathematics curriculum, in addition to career skills, introduces skills that ensure the development of society and individual admirable characteristics. The new 2020 secondary school curriculum also includes and specifies the skills needed for active engagement in societal processes, including civil and global competence.

Table 1

Transversal skills in secondary school mathematics curriculums

\begin{tabular}{|c|c|c|c|}
\hline $\begin{array}{l}\text { Secondary } \\
\text { school } \\
\text { mathematics } \\
\text { curriculum }\end{array}$ & $\begin{array}{l}\text { Transversal skills required } \\
\text { to address secondary school } \\
\text { mathematical challenges }\end{array}$ & $\begin{array}{c}\text { Transversal skills required for } \\
\text { the use of different teaching } \\
\text { methods }\end{array}$ & $\begin{array}{l}\text { Transversal skills } \\
\text { needed for everyday } \\
\text { life }\end{array}$ \\
\hline $\begin{array}{l}\text { Mathematics } \\
\text { curriculum } \\
1940\end{array}$ & $\begin{array}{l}\text { - One of the objectives of } \\
\text { learning geometry is the } \\
\text { development of the spatial } \\
\text { imagination } \\
\text { - when solving construction } \\
\text { exercises, it is necessary to } \\
\text { use all phases of solution: } \\
\text { analysis, design, mathema- } \\
\text { tical proof, and research. } \\
\text { Examples of task solving: } \\
\text { - Prove that square root of } 2 \text { is } \\
\text { a rational number } \\
\text { - explore the approximate } \\
\text { value of square root of } 2 \\
\text { - generalize the specified } \\
\text { process to all non-repeating } \\
\text { decimal numbers }\end{array}$ & None & None \\
\hline $\begin{array}{l}\text { Mathematics } \\
\text { curriculum. } \\
\text { Grades V-XI } \\
1949\end{array}$ & $\begin{array}{l}\text { - students should be taught to } \\
\text { draw and analyse diagrams } \\
\text { and charts } \\
\text { - students need to develop } \\
\text { spatial imagination, logical } \\
\text { thinking, and } \\
\text { resourcefulness } \\
\text { - when solving construction } \\
\text { exercises, it is necessary to } \\
\text { use all phases of solution: } \\
\text { analysis, design, mathema- } \\
\text { tical proof, and research }\end{array}$ & $\begin{array}{l}\text { - The aim of mathematics is to } \\
\text { develop student's skills to work } \\
\text { rationally and independently } \\
\text { - students interest in mathematics is } \\
\text { particularly increased by extra } \\
\text { curriculum activities (after school } \\
\text { mathematics, school papers, } \\
\text { evenings with mathematical games, } \\
\text { etc.). } \\
\text { - students should develop } \\
\text { persistence in achieving the stated } \\
\text { objective }\end{array}$ & $\begin{array}{l}\text { - The aim of } \\
\text { mathematics is to } \\
\text { develop student's } \\
\text { skills required for } \\
\text { practical purposes } \\
\text { - training for } \\
\text { practical work of the } \\
\text { students which will } \\
\text { not continue } \\
\text { education has to be } \\
\text { concluded }\end{array}$ \\
\hline $\begin{array}{l}\text { Mathematics } \\
\text { curriculum. } \\
\text { Grades V-XI } \\
1953\end{array}$ & $\begin{array}{l}\text { - The aim of mathematics is to } \\
\text { develop student's spatial } \\
\text { imagination and logical } \\
\text { thinking } \\
\text { - students should be taught to } \\
\text { draw and analyse diagrams } \\
\text { and charts }\end{array}$ & $\begin{array}{l}\text { - The aim of mathematics is to } \\
\text { develop student's skills to work } \\
\text { rationally and independently } \\
\text { - students interest in mathematics is } \\
\text { particularly increased by extra } \\
\text { curriculum activities (after school } \\
\text { mathematics, school papers, } \\
\text { evenings with mathematical games, } \\
\text { etc.). }\end{array}$ & $\begin{array}{l}\text { - The aim of teaching } \\
\text { mathematics in } \\
\text { secondary school is } \\
\text { to provide students } \\
\text { with real life } \\
\text { knowledge and to } \\
\text { develop the skills to } \\
\text { apply this knowledge }\end{array}$ \\
\hline
\end{tabular}




\begin{tabular}{|c|c|c|c|}
\hline $\begin{array}{l}\text { Secondary } \\
\text { school } \\
\text { mathematics }\end{array}$ & $\begin{array}{l}\text { Transversal skills required } \\
\text { to address secondary school } \\
\text { mathematical challenges }\end{array}$ & $\begin{array}{l}\text { Transversal skills required for } \\
\text { the use of different teaching } \\
\text { methods }\end{array}$ & $\begin{array}{c}\text { Transversal skills } \\
\text { needed for everyday } \\
\text { life }\end{array}$ \\
\hline & $\begin{array}{l}\text { - students should be capable } \\
\text { of generalizing the solution } \\
\text { - when solving more difficult } \\
\text { construction exercises, it is } \\
\text { necessary to use all phases of } \\
\text { solution: analysis, design, } \\
\text { mathematical proof, and } \\
\text { research }\end{array}$ & $\begin{array}{l}\text { - students should develop } \\
\text { persistence in achieving the stated } \\
\text { objective } \\
\text { - a great deal of attention should be } \\
\text { paid to organising the students } \\
\text { individual work }\end{array}$ & $\begin{array}{l}\text { for practical } \\
\text { purposes } \\
\text { - training for } \\
\text { practical work of the } \\
\text { students which will } \\
\text { not continue } \\
\text { education has to be } \\
\text { concluded }\end{array}$ \\
\hline $\begin{array}{l}\text { Mathematics } \\
\text { curriculum. } \\
\text { Grades V-XI } \\
1958\end{array}$ & $\begin{array}{l}\text { - The aim of mathematics is to } \\
\text { develop student's spatial } \\
\text { imagination, } \\
\text { resourcefulness, creativity } \\
\text { - students should be taught to } \\
\text { draw and analyse diagrams } \\
\text { and charts } \\
\text { - only equation systems that } \\
\text { are easily interpreted } \\
\text { geometrically should be } \\
\text { taught. } \\
\text { - the teacher needs to get } \\
\text { students to learn the idea of a } \\
\text { functional relationship. How } \\
\text { to compose, solve and } \\
\text { analyse equations. }\end{array}$ & $\begin{array}{l}\text { - The aim of mathematics is to } \\
\text { develop student's skills to work } \\
\text { rationally and independently } \\
\text { - students should develop } \\
\text { persistence in achieving the stated } \\
\text { objective } \\
\text { - pupils should acquire skills in the } \\
\text { use of calculating tools and } \\
\text { different measuring instruments } \\
\text { - special attention should be paid to } \\
\text { the organisation of students' } \\
\text { individual work inside and outside } \\
\text { the classroom } \\
\text { - to increase students' interest in } \\
\text { mathematics, it is important to } \\
\text { organise extra curriculum activities } \\
\text { (after school mathematics, school } \\
\text { papers, evenings with mathematical } \\
\text { games, etc.). }\end{array}$ & $\begin{array}{l}\text { - Teaching of } \\
\text { mathematics serves } \\
\text { to prepare pupils for } \\
\text { future practical } \\
\text { work and helps to } \\
\text { choose future career }\end{array}$ \\
\hline $\begin{array}{l}\text { Mathematics } \\
\text { curriculum } \\
\text { for } \\
\text { secondary } \\
\text { schools. } \\
\text { Grades IX- } \\
\text { XI } 1965\end{array}$ & $\begin{array}{l}\text { - The aim of mathematics is to } \\
\text { develop students logical } \\
\text { thinking } \\
\text { - pupils should be able to use } \\
\text { mathematical induction to } \\
\text { obtain new formulas } \\
\text { - the topic "repetition" } \\
\text { generalises and compiles the } \\
\text { entire course of the geometry }\end{array}$ & $\begin{array}{l}\text { - Teacher should focus on teaching } \\
\text { methods that stimulate pupils' } \\
\text { activity and conscientious learning } \\
\text { - the curriculum provides } \\
\text { possibilities for the use of different } \\
\text { methodological techniques in a } \\
\text { specific material presentation } \\
\text { - students should be prepared to } \\
\text { work individually } \\
\text { - students must be prepared to work } \\
\text { with books, manuals and other } \\
\text { literature, tables, and charts } \\
\text { individually }\end{array}$ & $\begin{array}{l}\text { - The aim of teaching } \\
\text { mathematics in } \\
\text { secondary school is } \\
\text { to achieve a level of } \\
\text { knowledge and skills } \\
\text { that is indispensable } \\
\text { for successful } \\
\text { practical work and } \\
\text { to provide them with } \\
\text { sufficient knowledge } \\
\text { necessary for other } \\
\text { school subjects }\end{array}$ \\
\hline $\begin{array}{l}\text { Mathematics } \\
\text { curriculum } \\
\text { for } \\
\text { secondary } \\
\text { schools. } \\
\text { Grades IX- } \\
\text { XI } 1968\end{array}$ & $\begin{array}{l}\text { - The aim of mathematics is to } \\
\text { develop students logical } \\
\text { thinking } \\
\text { - pupils should be able to use } \\
\text { mathematical induction to } \\
\text { obtain new formulas } \\
\text { - the topic "repetition" } \\
\text { generalises and compiles the } \\
\text { entire course of the geometry }\end{array}$ & $\begin{array}{l}\text { - Calculations must be performed } \\
\text { mainly with logarithmic ruler } \\
\text { - teacher should focus on teaching } \\
\text { methods that stimulate pupils' } \\
\text { activity and conscientious learning } \\
\text { - the curriculum provides } \\
\text { possibilities for the use of different } \\
\text { methodological techniques in a } \\
\text { specific material presentation } \\
\text { - students should be prepared to } \\
\text { work individually with books, } \\
\text { manuals and other literature, tables, } \\
\text { and charts }\end{array}$ & $\begin{array}{l}\text { - The aim of teaching } \\
\text { mathematics in } \\
\text { secondary school is } \\
\text { to achieve a level of } \\
\text { knowledge and skills } \\
\text { that is indispensable } \\
\text { for successful } \\
\text { practical work and } \\
\text { to provide them with } \\
\text { sufficient knowledge } \\
\text { necessary for other } \\
\text { school subjects }\end{array}$ \\
\hline
\end{tabular}




\begin{tabular}{|c|c|c|c|}
\hline $\begin{array}{l}\text { Secondary } \\
\text { school } \\
\text { mathematics } \\
\text { curriculum }\end{array}$ & $\begin{array}{l}\text { Transversal skills required } \\
\text { to address secondary school } \\
\text { mathematical challenges }\end{array}$ & $\begin{array}{l}\text { Transversal skills required for } \\
\text { the use of different teaching } \\
\text { methods }\end{array}$ & $\begin{array}{c}\text { Transversal skills } \\
\text { needed for everyday } \\
\text { life }\end{array}$ \\
\hline $\begin{array}{l}\text { Mathematics } \\
\text { curriculum } \\
\text { for } \\
\text { secondary } \\
\text { schools. } \\
\text { Grades IX- } \\
\text { XI } 1975\end{array}$ & $\begin{array}{l}\text { - The aim of mathematics is to } \\
\text { develop students logical } \\
\text { thinking } \\
\text { - pupils should be able to use } \\
\text { mathematical induction to } \\
\text { obtain new formulas } \\
\text { - the topic "repetition" } \\
\text { generalises and compiles the } \\
\text { entire course of the geometry }\end{array}$ & $\begin{array}{l}\text { - Teacher should focus on teaching } \\
\text { methods that stimulate pupils' } \\
\text { activity and conscientious learning } \\
\text { - students should be prepared to } \\
\text { work individually } \\
\text { - students must be prepared to work } \\
\text { with books, manuals and other } \\
\text { literature, tables, and charts } \\
\text { - the curriculum provides } \\
\text { possibilities for the use of different } \\
\text { methodological techniques in a } \\
\text { specific material presentation } \\
\text { - the logarithmic ruler should be } \\
\text { used as a typical computing tool }\end{array}$ & $\begin{array}{l}\text { - The aim of teaching } \\
\text { mathematics in } \\
\text { secondary school is } \\
\text { to achieve a level of } \\
\text { knowledge and skills } \\
\text { that is indispensable } \\
\text { for successful } \\
\text { practical work and } \\
\text { to provide them with } \\
\text { sufficient knowledge } \\
\text { necessary for other } \\
\text { school subjects }\end{array}$ \\
\hline $\begin{array}{l}\text { Mathematics } \\
\text { curriculum. } \\
\text { Grades IX- } \\
\text { XI } 1981\end{array}$ & $\begin{array}{l}\text { - The aim of mathematics is to } \\
\text { develop students logical } \\
\text { thinking and spatial } \\
\text { imagination } \\
\text { - students should study } \\
\text { functions and get an idea of } \\
\text { the deductive nature of } \\
\text { mathematics } \\
\text { - students need a systematic } \\
\text { knowledge } \\
\text { - mathematical proof must } \\
\text { be used to acquire theoretical } \\
\text { knowledge } \\
\text { - the acquisition of new } \\
\text { knowledge needs to be linked } \\
\text { to the generalisation of the } \\
\text { previously acquired } \\
\text { - special attention should be } \\
\text { paid to the derivative and to } \\
\text { the interpretation of the } \\
\text { findings obtained }\end{array}$ & $\begin{array}{l}\text { - Teaching methods that stimulate } \\
\text { students' activity should be used } \\
\text { and methods that stimulate } \\
\text { conscientious learning } \\
\text { - students should be provided with } \\
\text { general information on electronic } \\
\text { computing } \\
\text { - teaching should use methods that } \\
\text { develop students' skills required to } \\
\text { work individually, rationally, and } \\
\text { creative } \\
\text { - students should be prepared to } \\
\text { work with books, manuals and } \\
\text { other literature, tables, and charts } \\
\text { - extra curriculum activities can } \\
\text { help to raise students' mathematical } \\
\text { level }\end{array}$ & $\begin{array}{l}\text { - Linear } \\
\text { programming } \\
\text { contributes to an } \\
\text { informed perception } \\
\text { of mathematical } \\
\text { methods to be used in } \\
\text { manufacturing }\end{array}$ \\
\hline $\begin{array}{l}\text { Secondary } \\
\text { education } \\
\text { curriculum in } \\
\text { mathematics } \\
1993\end{array}$ & $\begin{array}{l}\text { - The aim of mathematics is to } \\
\text { develop general intellectual } \\
\text { capacity and skills, including } \\
\text { thinking techniques and } \\
\text { methods } \\
\text { - students should understand } \\
\text { and study the inherent } \\
\text { functional relationships and } \\
\text { have spatial understanding } \\
\text { of the position of geometrical } \\
\text { figures } \\
\text { - students should be able to } \\
\text { compare, prove identity, } \\
\text { simplify, analyse }\end{array}$ & $\begin{array}{l}\text { - Students should be able to use } \\
\text { micro-calculators } \\
\text { - students should develop skills } \\
\text { necessary for intellectual work }\end{array}$ & None \\
\hline $\begin{array}{l}\text { Mathematics. } \\
\text { Grades 10- } \\
\text { 12. Sample } \\
\text { of } \\
\text { curriculum } \\
2010\end{array}$ & $\begin{array}{l}\text { Students should be able to: } \\
\text { - formulate a problem and } \\
\text { raise a hypothesis } \\
\text { - form an argument }\end{array}$ & $\begin{array}{l}\text { Students should be able to: } \\
\text { - search for information } \\
\text { - to use an ICT } \\
\text { - present individual and group } \\
\text { work }\end{array}$ & $\begin{array}{l}\text { - Students should } \\
\text { realise the } \\
\text { importance of spatial } \\
\text { imaginations and } \\
\text { modelling in different }\end{array}$ \\
\hline
\end{tabular}




\begin{tabular}{|c|c|c|c|}
\hline $\begin{array}{l}\text { Secondary } \\
\text { school } \\
\text { mathematics }\end{array}$ & $\begin{array}{l}\text { Transversal skills required } \\
\text { to address secondary school } \\
\text { mathematical challenges }\end{array}$ & $\begin{array}{c}\text { Transversal skills required for } \\
\text { the use of different teaching } \\
\text { methods }\end{array}$ & $\begin{array}{c}\text { Transversal skills } \\
\text { needed for everyday } \\
\text { life }\end{array}$ \\
\hline & $\begin{array}{l}\text { - carry out mathematical } \\
\text { proof } \\
\text { - assess the reliability and } \\
\text { relevance of the results } \\
\text { - see analogy, process trends, } \\
\text { and generalize }\end{array}$ & $\begin{array}{l}\text { - create report } \\
\text { - to collaborate in research and } \\
\text { practical work } \\
\text { - to formulate a reasoned opinion }\end{array}$ & $\begin{array}{l}\text { professions and areas } \\
\text { of everyday life } \\
\text { - It is important to } \\
\text { improve students' } \\
\text { understanding of the } \\
\text { role of mathematics in } \\
\text { everyday life and the } \\
\text { role of mathematics in } \\
\text { other sciences, society, } \\
\text { and individual } \\
\text { development. }\end{array}$ \\
\hline $\begin{array}{l}\text { Mathematics } \\
\text { I. Basic } \\
\text { course } \\
\text { curriculum } \\
\text { for general } \\
\text { secondary } \\
\text { education } \\
2020\end{array}$ & $\begin{array}{l}\text { - Solving the problem } \\
\text { mathematically means } \\
\text { identifying structures, } \\
\text { systems, relationships, } \\
\text { creating generalisations and } \\
\text { proving them } \\
\text { - data can be mathematically } \\
\text { processed, analysed, and } \\
\text { interpreted for reasoned and } \\
\text { relevant decisions } \\
\text { - student can make transition } \\
\text { between specific and general } \\
\text { - think inductively and } \\
\text { deductively }\end{array}$ & $\begin{array}{l}\text { - Students can collaborate to } \\
\text { prove, critically assess the various } \\
\text { offers and information, evaluate, } \\
\text { and explain what it means to solve } \\
\text { the problem } \\
\text { students should be able to: } \\
\text { - collect information } \\
\text { independently using digital tools } \\
\text { - set objectives and criteria for } \\
\text { assessing whether the goal has been } \\
\text { achieved, plan and implement } \\
\text { steps to achieve that } \\
\text { - carefully plan the data collection } \\
\text { and presentation process, develop } \\
\text { students' thinking skills }\end{array}$ & $\begin{array}{l}\text { - To improve foreign } \\
\text { language skills, it is } \\
\text { recommended to use } \\
\text { sources in different } \\
\text { languages } \\
\text { - the student is } \\
\text { capable to contribute } \\
\text { to improving the } \\
\text { current situation, } \\
\text { accepting complex } \\
\text { challenges, and } \\
\text { maintaining } \\
\text { emotional balance } \\
\text { and openness in } \\
\text { times of uncertainty } \\
\text { - students can explain } \\
\text { and justify their } \\
\text { views on } \\
\text { interrelations, assess } \\
\text { the interaction } \\
\text { between individuals, } \\
\text { society, and the } \\
\text { environment } \\
\text { - be able to refuse if } \\
\text { the initiative does not } \\
\text { meet the values and } \\
\text { is able to defy the } \\
\text { pressure from others }\end{array}$ \\
\hline
\end{tabular}

Comparing the three proposed domains of transversal skills there are common features in their development. They have been topical in line with the everyday needs and requirements of the labour market. However, there are also specific features in each of the groups. The transversal skills needed to address mathematics challenges are determined by the mathematics content and its variability. This transversal skill domain is also the most resilient and has not actually experienced significant changes.

The skills needed to use different teaching methods depend directly on the philosophical approach to the learning process. This domain is also affected by important skills needed for lifelong learning. Which points to the necessity to acquire skills to be able to fully improve their knowledge and skills to be competitive in the labour market.

The transversal skills needed for everyday life and that can be developed through secondary school mathematics are influenced by societal variability and impact of the political regime. Until the restoration of Latvia's independence in 1990 important are skills required for practical life and career with heavy emphasis on skills required for blue colour workers. Since 1993 the need for skills to secure democratic processes and increasing citizenship activity increased significantly. Although researched 
transversal skills are viewed from school and teaching perspective, these domains are not isolated or unambiguous and can overlap with each other.

The new secondary school mathematics curriculum is in line with other countries secondary school curriculums. The Australian secondary school mathematics curriculum emphasizes transversal skills like literacy, numeracy, ICT skills, critical and creative thinking, personal and social capacity, ethical awareness, intercultural understanding (Senior Secondary Mathematics..., 2018). In return, the Hong Kong Secondary mathematics curriculum aims to develop transversal skills such as basic skills (communication skills, mathematical skills, ICT skills), thinking skills (critical thinking skills, creativity, problem solving skills), personal and social skills (self-driving skills, self-learning skills, collaboration skills) (Mathematics Education Key..., 2017). In the context of secondary school mathematics problem solving skills students must have skills (Mathematics, 2012, Common Core State..., 2010, (Mathematics Education Key, 2017, Senior Secondary Mathematics..., 2018) including problem solving as a complex collaborative problem-solving skill (Mathematics Education Key..., 2017). This similarity also points to the importance of transversal skills in addressing current challenges and the experience of Latvia can be generalized.

\section{Conclusions}

Although the term 'transversal skills' is included in the secondary education curriculum only since 2020, it can be concluded that most of the transversal skills were present in all 11 analysed curriculums from previous years.

Transversal skills from the school perspective can be grouped into three domains:

- transversal skills required to address secondary school mathematical challenges, thinking skills (logical, critical, creative, systemic thinking) and problem-solving skills;

- transversal skills required for the use of different teaching methods, collaboration skills, communication skills, skills to work individually, planning skills, information search, processing, adaptation skills, presentation skills, decision-making skills and digital skills;

- transversal skills needed for everyday life and that can be developed through secondary school mathematics, career skills, creativity and entrepreneurship, intercultural awareness and civic engagement.

The research shows that the transversal skills required to solve mathematical tasks are essentially determined by the content and have not changed significantly over time. The role of research tasks has slightly increased and the role of proof has been diminished. The skills needed to use different learning methods have changed over time in the context of a paradigm shift. From 1990 political regime has changed in Latvia and that has led to a paradigm shift from teacher-centred to student-centred learning process. It had determined the change of emphasis of teaching methods from individual work to teamwork. The third domain of transversal skills, which contains all skills needed for everyday life and which can be developed through mathematics, has changed fundamentally. Until the recovery of Latvia's independence in 1990, the primary emphasis in secondary school mathematics was placed on career skills and on the skills needed in practical activities. The new secondary school mathematics curriculum implemented in 2020 accentuates skills needed for lifelong learning like digital skills, collaboration skills and the promotion of civic activities.

Therefore, teachers are advised (1) to study the definition of different transversal skills, (2) to recognize the skills already familiar to them, (3) to connect with and utilize their past experience in transversal skill development in the classroom, (4) to supplement the everyday learning process with methods required to develop those particular transversal skills that are new and have been included in secondary school curriculum only recently.

\section{Bibliography}

1. Care E., Luo R. (2016). Assessment of Transversal Competencies: Policy and Practice in the Asia Pacific Region. Bangkok: UNESCO. Retrieved from https://neqmap.bangkok.unesco.org/wpcontent/uploads/2019/09/246590eng.pdf

2. Common Core State Standards for Mathematics. (2010). Retrieved from https://ccsso.org/sites/default/files/2017-12/ADA\%20Compliant\%20Math\%20Standards.pdf 
3. European Commission. (2018). Proposal for a Council Recommendation on Key Competences for LifeLong Learning. Retrieved from https://eur-lex.europa.eu/legalcontent/EN/TXT/PDF/?uri=CELEX:52018SC0014\&from=EN

4. European Commission. (2019). Key competences for lifelong learning. Luxembourg: Publications Office of the European Union. doi: 10.2766/569540

5. Flora N. (2014). Contribution to Gender Studies for Competences Achievement Stipulated by National Qualifications. Journal of Research in Gender Studies, 4(2), 741-750.

6. Gordon J., Halasz G., Krawczyk M., Leney T., Michel A., Pepper D., Putkiewicz E., Wisniewski J. (2009). Key Competences in Opening doors for lifelong learners across the school curriculum and teacher education. Warsaw: CASE Network Report. Retrieved from https://www.econstor.eu/bitstream/10419/87621/1/613705459.pdf

7. Ipate D.M., Mitran P.C., Pârvu I. (2014). Identification of Employability Skills - Starting Point for the Curriculum Design process. Economics, Management, and Financial Markets, 9(1), 237-246.

8. Lama G. (2020). Case Study: Transversal Skills in Secondary School Mathematics. In V. Dislere (Ed.), The Proceedings of the International Scientific Conference Rural Environment. Education. Personality (REEP), 13. Jelgava: Latvia University of Life Sciences and Technologies, 93-100. doi: 10.22616/REEP.2020.011

9. Matemātikas programma V-XI klasei [Mathematics curriculum. Grades V-XI]. (1949). Latvijas PSR Izglītības ministrija. Rīga: Latvijas Valsts izdevniecība. (in Latvian)

10. Matemātikas programma V-XI klasei [Mathematics curriculum. Grades V-XI]. (1953). Latvijas PSR Izglītības ministrija. Riga: Latvijas Valsts izdevniecība. (in Latvian)

11. Matemātikas programma V-XI klasei 1958./59. mācību gadam [Mathematics curriculum for school year 1958./59. Grades V-XI]. (1958). Latvijas PSR Izglītības ministrija. Rīga: Latvijas Valsts izdevniecība. (in Latvian)

12. Matemātikas programma IX-XI klasei [Mathematics curriculum for secondary schools. Grades IX-XI]. (1975). Latvijas PSR Izglītîbas ministrija. Rīga: Zvaigzne. (in Latvian)

13. Matemātikas programma vidusskolu IX-XI klasēm 1965./66. mācību gadam [Mathematics curriculum for secondary school year 1965./66. Grades IX-XI]. (1965). Latvijas PSR Izglitīibas ministrija. Rīga: Liesma. (in Latvian)

14. Matemātikas programmas vidusskolu IX-XI klasēm [Mathematics curriculum for secondary schools. Grades IX-XI]. (1968). Latvijas PSR Izglītības ministrija. Rīga: Zvaigzne. (in Latvian)

15. Matemātikas programma IX-XI klasei [Mathematics curriculum. Grades IX-XI]. (1981). Latvijas PSR Izglìtības ministrija. Rīga: Zvaigzne. (in Latvian)

16. Matemātika 10.-12. klasei. Mācību priekšmeta programmas paraugs [Mathematics. Grades 10-12. Sample of curriculum]. (2010). Retrieved from https://www.siic.lu.lv/fileadmin/user_upload/lu_portal/projekti/siic/Macibu_prieksmetu_progra mmas_10.-12.kl/MPP_matematika.pdf in Latvian)

17. Mathematics. (2012). Swedish National Agency for Education. Upper-Secondary school mathematics curriculum. Retrieved from https://www.skolverket.se/download/18.4fc05a3f164131a74181063/1535372298267/Mathemati cs-swedish-school.pdf

18. Mathematics Education Key Learning Area Curriculum Guide (Primary 1 - Secondary 6).

(2017). The Hong Kong Curriculum Development Council. Retrieved from https://www.edb.gov.hk/attachment/en/curriculumdevelopment/kla/ma/curr/ME_KLACG_eng_2017_12_08.pdf

19. OECD. (2019). OECD Future of Educational and Skills 2030: OECD Learning Compass 2030. Paris: OECD Publishing. Retrieved from http://www.oecd.org/education/2030-project/teachingand-learning/learning/learning-compass2030/OECD_Learning_Compass_2030_Concept_Note_Series.pdf

20. Senior Secondary Mathematics Curriculum. (2018). The Australian Curriculum. Retrieved from https://www.australiancurriculum.edu.au/download?view=ss

21. Skola 2030. (2018). Izglìtība mūsdienīgai lietpratībai: mācību satura un pieejas apraksts [Education for Modern Competence: a Description of the Content and Approach of Learning]. Retrieved from https://static.lsm.lv/documents/ge.pdf (in Latvian) 
22. Tartakovskis V.A., Delone V.N., Grebenča M.K., Pokrovskis S., Suvorovs E.G., Lifšics E., Burmakina A. (1940). Matēmatikas programa [Mathematics curriculum]. Rīga: VAPP Pedagoǵisko rakstu apgādniecība. (in Latvian)

23. Trzmiel B. (2015). Transversal Skills in TVET: Policy Implications. Paris: UNESCO. Retrieved from https://unesdoc.unesco.org/ark:/48223/pf0000234738

24. Vidējās izglìtības standarts matemātikā [Secondary education curriculum in mathematics]. (1993). Latvijas Republikas izglītîbas ministrija. Rīga: Izglìitības ministrija. (in Latvian)

25. Vilciņš J., Balanda S., France I., Jaunzeme E., Lāce G., Zuters V. (2020). Matemātika I. Pamatkursa programmas paraugs vispārējai vidējai izglītībai [Mathematics I. Basic course curriculum for general secondary education]. Retrieved from https://mape.skola2030.lv/resources/351 (in Latvian)

26. Vorobjovs A. (2017). Adolescents' Mathematical Competence Formation Influencing Factors. In V. Dislere (Ed.), The Proceedings of the International Scientific Conference Rural Environment. Education. Personality (REEP), 10. Jelgava: LLU, 315-320. Retrieved from https://llufb.llu.lv/conference/REEP/2017/Latvia-Univ-Agricult-REEP-2017_proceedings-315-320.pdf

27. Vorobjovs A. (2019). Factors Affecting the Result of a Secondary School Math Exam. In V. Dislere (Ed.), The Proceedings of the International Scientific Conference Rural Environment. Education. Personality (REEP), 12. Jelgava: Jelgava: Latvia University of Life Sciences and Technologies, 203-209. doi: 10.22616/REEP.2019.026 